\title{
Bronze Baby Syndrome: a New Porphyrin-Related Disorder
}

\author{
FIRMINO F. RUBALTELLI, ${ }^{(13)}$ GIULIO JORI, AND ELENA REDDI \\ Department of Pediatrics and C.N.R. Center for the Physiology and Biochemistry of Hemocyanins and Other Metallo- \\ Proteins, Institute of Animal Biology, University of Padova, Padova, Italy
}

\begin{abstract}
Summary
The absorption spectrum of serum samples from infants with bronze baby syndrome (BBS) showed spectral features typical of bilirubin (i.e., $\lambda \max$ at approximately $460 \mathrm{~nm}$ ), as well as an intense band peaking around $400 \mathrm{~nm}$ and a generalized broad absorbance in the near-UV and in the $600-700 \mathrm{~nm}$ spectral region. The two latter features were not observed in the absorption spectra of control sera; moreover, the BBS sera exhibited multiband emission spectra with maxima at 585,619 , and $670 \mathrm{~nm}$. This finding indicates that the 400-nm absorption band does not reflect the presence of residual hemoglobin in the sera because hemoproteins are known to be nonfluorescent in the red region. Instead the observed emission spectra are characteristic of porphyrin compounds. The porphyrins extracted from BBS sera were analyzed chromatographically. The results of paper chromatography led to the conclusion that the two porphyrins present in the ether fraction are $\mathrm{Cu}^{2+}$-proto and $\mathrm{Cu}^{2+}$-coproporphyrin, whereas the porphyrin in the aqueous phase is $\mathrm{Cu}^{2+}$-uroporphyrin.

Visible light-irradiation of diluted sera from BBS newborn infants caused an increase of the brown color of the solution corresponding with a disappearance of the typical porphyrin fluorescence and an increase of the absorbance in the near-UV and red spectral regions. Extraction of porphyrins from 15-min irradiated BBS sera showed that an essentially total destruction had occurred.

In order to verify the responsibility of $\mathrm{Cu}^{2+}$-porphyrins in inducing the BBS discoloration, we irradiated 8-ml samples of serum obtained from normal cord blood in presence of $\mathrm{Cu}^{2+}$-proto, $\mathrm{Cu}^{2+}$ copro, and $\mathrm{Cu}^{2+}$-uroporphyrin, which were added at a concentration of $3.28 \mu \mathrm{g} / \mathrm{ml}$. $\mathrm{Cu}^{2+}$-porphyrins were slowly destroyed and the consequent spectral changes closely resembled those observed from BBS sera from phototreated patients. The addition of equimolar bilirubin to the aqueous solution of $\mathrm{Cu}^{2+}$-porphyrins bound to albumin enhanced the first order rate constant for porphyrin photodestruction from $0.12 \mathrm{sec}^{-1}$ to $0.49 \mathrm{sec}^{-1}$.
\end{abstract}

\section{Abbreviations}

BBS, bronze baby syndrome

UV, ultraviolet

Bronze baby syndrome (BBS) is a rare pathologic condition and is related to phototherapy of neonatal jaundice, which causes the appearance of grey-brown discoloration of skin, serum, and urine $(3,7)$. The mechanisms responsible for the onset of BBS in phototreated babies and the chemical nature of the abnormal pigment(s) have not been identified, although the appearance of the syndrome is subsequent to an abrupt rise in conjugated bilirubin and bile acid levels $(3,7)$. The discoloration clears after discontinuation of phototherapy.

We observed two newborn infants who developed BBS after phototherapeutic treatment for unconjugated hyperbilirubinemia. The jaundice was ascribed to Rh-hemolytic disease in one case, and to prematurity in the other case (10). On the basis of spectroscopic and chromatographic studies performed on serum samples from the two patients, we propose a mechanism for the onset of BBS. The simultaneous presence of a high serum concentration of porphyrins and a high level of copper due to cholestasis leads to formation of $\mathrm{Cu}^{2+}$-porphyrins, which are converted to brown photoproducts during phototherapy via photosensitization by bilirubin.

\section{MATERIALS AND METHODS}

Serum samples were obtained from two newborn infants who developed BBS after phototherapy for neonatal jaundice. One patient was available for follow-up examination at 1 year of age. At that time, a blood sample was obtained. The clinical course of the two patients is described elsewhere (10). Samples of cord blood and aliquots of blood obtained for clinical purposes from newborns admitted to our unit for metabolic problems (hypoglycemia, hypocalcemia, hyperbilirubinemia, etc.) were used as controls. Some infants had been previously phototreated. In all cases, the sera were separated and either analyzed immediately or frozen at $-20^{\circ} \mathrm{C}$.

Porphyrin samples. Protoporphyrin IX was obtained from Porphyrin Products (Logan, Utah), coproporphyrin III and uroporphyrin III were supplied by Nippon Petrochemicals Co. (Tokyo, Japan). All porphyrins appeared to be homogeneous when assayed by thin layer chromatography in different solvent systems. The corresponding $\mathrm{Cu}^{2+}$-derivatives were synthesized by reaction of the free base porphyrins with $\mathrm{Cu}^{2+}$-acetate (1). The completeness of metal insertion was followed by the typical changes of porphyrin absorption spectrum in the $500-550 \mathrm{~nm}$ region (4). The porphyrin solutions were prepared by dissolving a known amount of porphyrin in a few drops of $0.1 \mathrm{M} \mathrm{NaOH}$ and then adding the desired volume of $0.1 \mathrm{M}$ phosphate buffer solution at $\mathrm{pH}$ 7.4. The porphyrin concentrations were estimated spectroscopically using the following $\epsilon_{\mathrm{M}}$ values: $\mathrm{Cu}^{2+}$-protoporphyrin, 107,143 at $400 \mathrm{~nm}$; $\mathrm{Cu}^{2+}$-coproporphyrin, 74,074 at $400 \mathrm{~nm}$; $\mathrm{Cu}^{2+}$-uroporphyrin, 413,000 at $400 \mathrm{~nm}$.

Analysis of serum porphyrins. The porphyrins were extracted from serum samples taking advantage of their partition coefficient in water and diethyl ether, according to the procedure detailed in Figure 1. The various fractions were analyzed by paper chromatography on Whatman No. 1 (descending technique); the various free base- or $\mathrm{Cu}^{2+}$-porphyrins were used as reference for the calculation of the $\mathrm{R}_{\mathrm{f}}$ values.

Spectroscopic studies. Absorption spectra were obtained by a Perkin Elmer mod. 576 spectrophotometer using matched quartz cuvettes of $1-\mathrm{cm}$ optical path. Fluorescence excitation and emission spectra were recorded by a Perkin Elmer MPF 4 spectrophotofluorimeter equipped with a red-sensitive phototube. The porphyrin samples were placed in $1-\mathrm{cm}$ thick quartz cuvettes thermostated at $20 \pm 1{ }^{\circ} \mathrm{C}$ and the $400-\mathrm{nm}$ excited fluorescence was observed at $90^{\circ}$ to the incident light beam. The emission in the $550-750 \mathrm{~nm}$ region was recorded using excitation and emission 


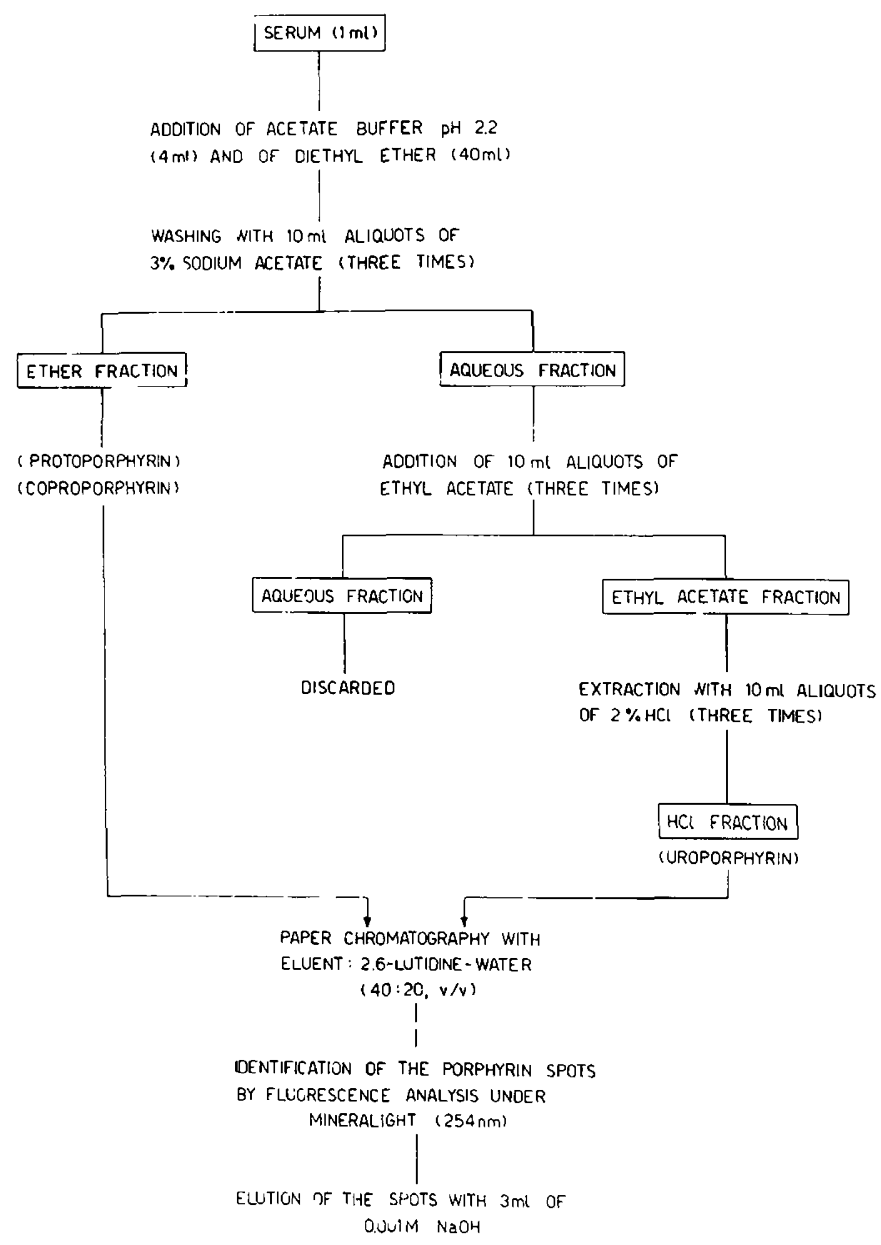

Fig. 1. Scheme of the procedure adopted for extraction and separation of serum porphyrins.

slits of $8 \mathrm{~nm}$. The instrument was operated in the ratio mode to avoid artifacts due to fluctuations of the light source.

Atomic absorption studies were performed with a Perkin Elmer 4000 AAS instrument which had been previously calibrated with known amounts of inorganic salts of the ions to be estimated.

Irradiation procedure. Typically, $60 \mu \mathrm{l}$ of sera from BBS patients were added to $1.8 \mathrm{ml}$ of $0.1 \mathrm{M}$ phosphate buffer at $\mathrm{pH} 7.4$ and irradiated at $20 \pm 1{ }^{\circ} \mathrm{C}$ in Pyrex test tubes of $1.2 \mathrm{~cm}$ diameter by four 250 watt incandescent light bulbs (Phillips mod. $13352 \mathrm{E}$, emission above $400 \mathrm{~nm}$ ). The infrared radiation was eliminated by circulating water. The irradiance in the $400-500 \mathrm{~nm}$ region was about $1 \mathrm{~mW} / \mathrm{cm}^{2}$ At fixed times, the irradiated samples were subjected to spectroscopic analyses. The same procedure was adopted to irradiate control sera from normal newborns and aqueous solutions of synthetic or commercial porphyrins added to cord blood serum or to $0.1 \mathrm{mM}$ serum albumin solutions in phosphate buffer at $\mathrm{pH}$ 7.4. In some experiments, bilirubin in $1: 1$ molar ratio with albumin was added to the irradiated solutions; the latter solutions were prepared as previously reported (6).

\section{RESULTS}

Spectroscopic studies on serum samples from BBS patients. The absorption spectrum of serum samples obtained from both BBS infants showed the spectral features typical of bilirubin (i.e., $\lambda \max$ at approximately $460 \mathrm{~nm}$ ), as well as an intense band peaking around $400 \mathrm{~nm}$ and a generalized broad absorbance in the nearUV and in the 600-700 $\mathrm{nm}$ spectral region. The two latter features were not observed in the absorption spectra of control sera; moreover, the BBS sera exhibited multiband emission spectra with maxima at 585,619 , and $670 \mathrm{~nm}$. This finding indicates that the $400 \mathrm{~nm}$ absorption band, at least in part, does not reflect the presence of residual hemoglobin in the sera because hemoproteins are known to be nonfluorescent in the red region (8). Instead, the observed emission spectra were characteristic of porphyrin compounds (5). Identical fluorescence emission properties were observed for the serum of one BBS patient at one year of age. At the same time, analysis of the metal ion content of BBS sera by atomic absorption spectroscopy showed an abnormal content of copper $(4-4.2 \mu \mathrm{g} / \mathrm{ml})$ i.e., about 4-times higher than in control sera $(0.8-$ $1.2 \mu \mathrm{g} / \mathrm{ml}$ ). The serum levels of other metal ions, such as zinc, cadmium and iron, were in the normal range. Serum copper levels were in the normal range for the BBS patient at one year of age.

In vitro irradiation of $B B S$ and control sera. Visible light-irradiation of diluted sera from BBS newborn infants or from one of the same infants at one year of age caused an increase of the brown color of the solution corresponding with a disappearance of the typical porphyrin fluorescence (Fig. 2) and an increase of the absorbance in the near-UV and red regions of the spectrum. Extraction of porphyrins from 15 min-irradiated BBS sera showed that an essentially total destruction had occurred. Only minor changes in the UV absorption spectrum of the sera were observed, which indicated that the protein components were relatively unaffected. The irradiation of sera from healthy newborns under the same experimental conditions induced no significant alterations throughout the UV and visible absorption spectrum with the exception of changes in absorption bands typical of bilirubin.

In order to verify the responsibility of $\mathrm{Cu}^{2+}$-porphyrins in inducing the BBS discoloration, we irradiated 8-ml samples of serum obtained from normal cord blood in presence of bilirubin $\left(1.7 \times 10^{-4} \mathrm{M}\right)$ and of $\mathrm{Cu}^{2+}$-proto, $\mathrm{Cu}^{2+}$-copro, and $\mathrm{Cu}^{2+}$-uroporphyrin, which were added at a concentration of $3.28 \mu \mathrm{g} / \mathrm{ml}$. As shown in Figure 3, $\mathrm{Cu}^{2+}$-porphyrins were slowly destroyed, and the consequent spectral changes closely resembled (Fig. 3) those observed for BBS sera from phototreated patients. Once again, no significant spectral changes were observed in the UV region, suggesting that the protein components of the serum were unaffected. The photoinduced destruction of $\mathrm{Cu}^{2+}$-porphyrins was barely detectable upon irradiation of the same compounds in aqueous solutions as well as of solutions obtained by adding the $\mathrm{Cu}^{2+}$-porphyrins $(3.30 \mu \mathrm{g} / \mathrm{ml})$ to adult serum having a very low bilirubin level $(0.2 \mathrm{mg} / \mathrm{dl})$. On the contrary, the addition of equimolar bilirubin to the aqueous solutions of $\mathrm{Cu}^{2+}$-porphyrins bound to albumin enhanced the first order rate constant for porphyrin photodestruction from $0.12 \mathrm{~s}^{-1}$ to $0.49 \mathrm{~s}^{-1}$.

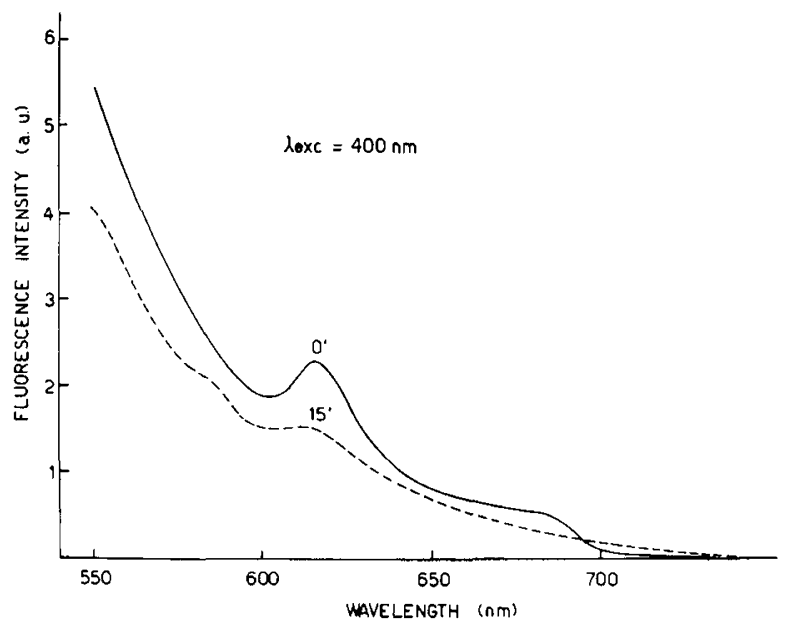

Fig. 2. Fluorescence emission spectrum of 30 -fold diluted serum (1.8 $\mathrm{ml}$ ) of a BBS newborn infant at zero irradiation time (-) and after 15 min of irradiation (----) at $20^{\circ} \mathrm{C}$ with four 250 watt tungsten lamps. Sepctra have been excited at $400 \mathrm{~nm}$. 

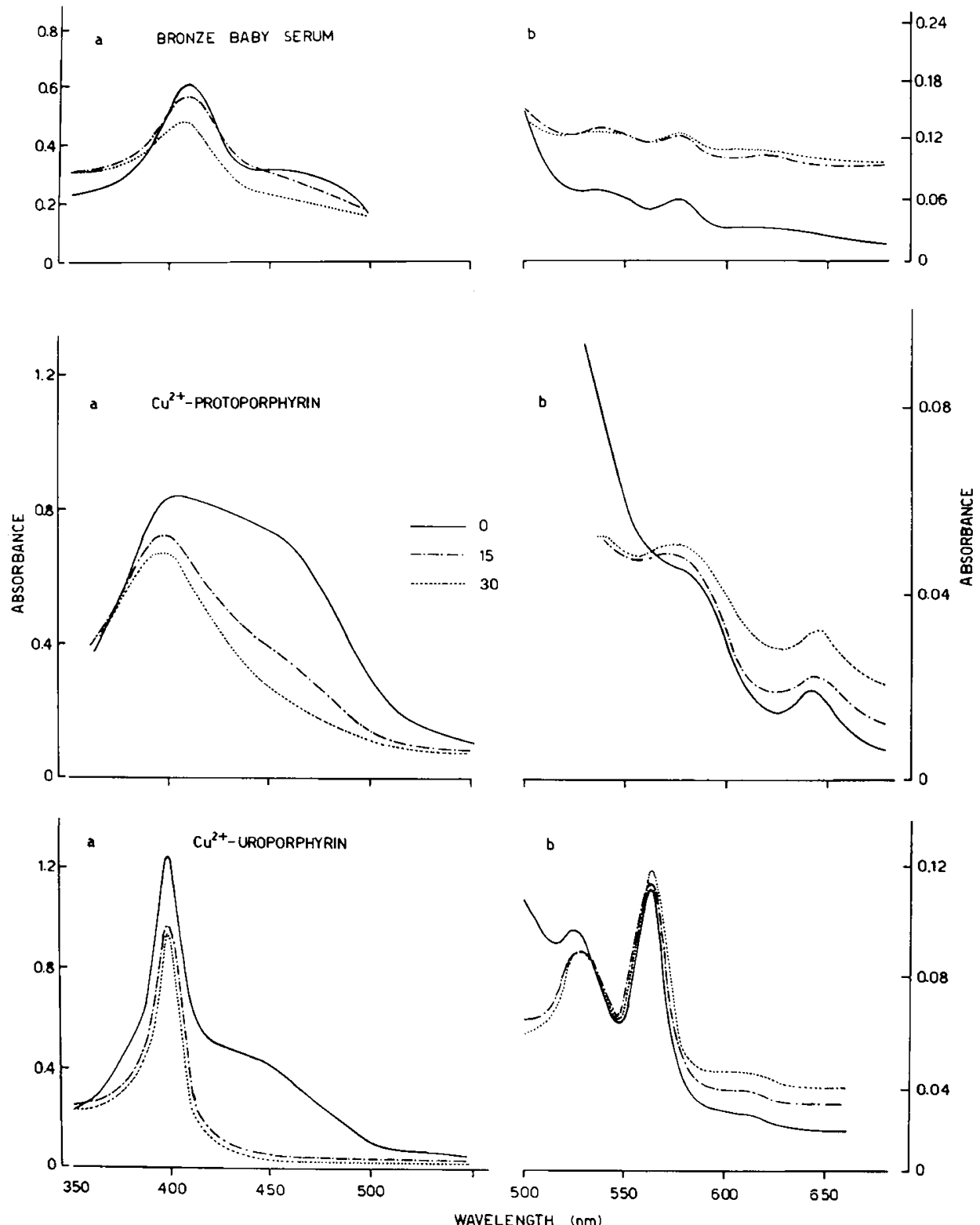

Fig. 3. Changes in the visible absorption spectrum of 30 -fold diluted BBS serum (1.8 $\mathrm{ml}$ ) (upper plot), and of 10 -fold diluted cord blood serum ( $8 \mathrm{ml}$ ) with bilirubin $\left(1.7 \times 10^{-4} \mathrm{M}\right)$ and with $3.28 \mu \mathrm{g} / \mathrm{ml} \mathrm{Cu}^{2+}$-protoporphyrin (middle plot) and $\mathrm{Cu}^{2+}$-uroporphyrin (lower plot) upon irradiation at $20^{\circ} \mathrm{C}$ with four 250 watt tungsten lamps. After 30 min of irradiation the residual absorption peaking at around $400 \mathrm{~nm}$ of the BBS serum is due to traces of serum hemoglobin.

Analysis and characterization of serum porphyrins. The porphyrins extracted from BBS sera according to the procedure described in Figure 1 were analyzed chromatographically using the three naturally present porphyrins, uroporphyrin III, coproporphyrin III, and protoporphyrin IX, as well as their $\mathrm{Cu}^{2+}$-complexes as reference standards. The $R_{f}$ values of the porphyrin spots are shown in Table 1. The spots were eluted from the paper with $3 \mathrm{ml}$ of $0.01 \mathrm{M} \mathrm{NaOH}$ after identification of the full area by fluorescence analysis. Control experiments with known amounts of porphyrins showed that the recoveries from the paper were higher than $30 \%$. The fluorescence emission and excitation spectra of the neutralized ( $\mathrm{pH} 7.5$ ) solutions of the eluted porphyrins present in BBS sera were typical of metallo-porphyrins (Fig. 4). Atomic absorption spectroscopy of the extracted fractions gave a copper content of $8.30 \mu \mathrm{g} / \mathrm{ml}$ (ether fraction) and of $3.83 \mu \mathrm{g} / \mathrm{ml}$ (ethyl acetate fraction). Owing to the insolubility of inorganic copper salts in the latter solvents, the copper present in these fractions must be associated with porphyrins. The results of copper analysis and of paper chromatography allow us to conclude that the two porphyrins present in the ether fraction are $\mathrm{Cu}^{2+}$-proto and $\mathrm{Cu}^{2+}$ coproporphyrin, whereas the porphyrin in the aqueous phase is $\mathrm{Cu}^{2+}$-uroporphyrin. We quantitated the amount of the three porphyrins isolated from BBS sera by comparing the fluorescence yields with those typical of the corresponding synthetic copperporphyrins. The data are shown in Table 1. The serum of the same patient at 1 year of age contained only traces of uroporphyrin, whereas the level of protoporphyrin was about three times higher than those of sera from controls of the same age.

\section{DISCUSSION}

Our findings show that sera from both BBS patients contain an abnormally high amount of porphyrins. Chromatographic separation of the porphyrins led to the conclusion that the main component is represented by $\mathrm{Cu}^{2+}$-protoporphyrin IX, although detectable amounts of $\mathrm{Cu}^{2+}$-coproporphyrin III and $\mathrm{Cu}^{2+}$-uropor- 
Table 1. Identification and quantitation of the porphyrin content present in $1 \mathrm{ml}$ of serum taken from two infants exhibiting

"bronze" baby syndrome when subjected to phototherapy for hyperbilirubinemia. The porphyrin concentration was estimated by fluorescence analysis after chromatographic separation on paper of serum extracts using 2,6-lutidine-water (40:20) as the eluent.

\begin{tabular}{lccc}
\hline \multirow{2}{c}{ Sample } & \multicolumn{3}{c}{$\begin{array}{c}\text { Amount recovered }(\mu \mathrm{g} / \mathrm{ml} \text { of se- } \\
\text { rum })\end{array}$} \\
\cline { 3 - 4 } & $\mathrm{R}_{\mathrm{f}}$ & 1st patient & 2nd patient \\
\hline Uroporphyrin & 0.00 & & \\
Coproporphyrin & 0.21 & & \\
Protoporphyrin & 0.70 & & \\
$\mathrm{Cu}^{2+}$-uroporphyrin & 0.00 & & \\
$\mathrm{Cu}^{2+}$-coproporphyrin & 0.27 & & \\
$\mathrm{Cu}^{2+}$-protoporphyrin & 0.76 & & \\
& 0.26 & 0.530 & 0.680 \\
Serum ether extract & & & \\
& 0.79 & 4.520 & 6.250 \\
Serum $\mathrm{HCl}$ extract & 0.00 & 0.920 & 0.807 \\
\hline
\end{tabular}

phyrin III are also present. These porphyrins appear to be devoid of appreciable photosensitizing efficiency, as demonstrated by the lack of significant alterations of the UV spectrum of irradiated BBS sera and of cord blood serum with added synthetic $\mathrm{Cu}^{2+}$ porphyrins. This fact is due to the well known dramatic shortening of the lifetime of porphyrin excited states as a consequence of $\mathrm{Cu}^{2+}$-binding with the tetrapyrrolic macrocycle (2). Our findings are in agreement with the clinical observations that show no detectable photoinduced damage occurring in BBS patients, which is in contrast with the high photosensitivity exhibited by porphyric patients (11). On the other hand, the onset of grey-brown discoloration appears to be a consequence of the photolability of $\mathrm{Cu}^{2+}$. porphyrins. Actually, $\mathrm{Cu}^{2+}$-porphyrins in BBS sera or in aqueous solutions, upon visible light-irradiation, are converted to brown photoproducts with enhanced absorption in the near-UV and red spectral regions. The presence of bilirubin increases the rate of photodegradation of $\mathrm{Cu}^{2+}$-porphyrins, suggesting that bilirubin acts as a photosensitizer in the process. The ability of bilirubin to photosensitize the chemical modification of several cell constituents has been largely documented (9).

On the basis of our findings, we suggest the following pathway for the onset of BBS in newborn infants: (1) the abnormally high serum levels of porphyrins present in these newborns are likely to be due to cholestasis, which also determines an enhanced copper level in the serum and in the liver. An increased porphyrin concentration has been found also in two cases of neonatal cholangeitis presenting an enhanced conjugated bilirubin level; (2) the coincidence of the two events induces the formation of $\mathrm{Cu}^{2+}$ porphyrins owing to the large affinity of the porphyrin tetrapyrrolic system for copper ions; (3) the presence of copper partially prevents enzymic conversion of the porphyrin molecule along the sequence uro $\rightarrow$ copro $\rightarrow$ protoporphyrin; this fact may explain the different pattern of porphyrins found in neonatal serum as compared with the serum of 1-year-old infant; and (4) $\mathrm{Cu}^{2+}$ porphyrins undergo photodestruction sensitized probably by bilirubin yielding photoproducts with generalized absorption in the near-UV and red spectral regions; thus, the brown discoloration.

In conclusion, it appears reasonable that BBS is an extremely rare condition owing to the fact that its onset requires the combined presence of hyperporphyrinemia, hyperbilirubinemia, cholestasis, and light treatment.

\section{REFERENCES AND NOTES}

I. Buchler, J. W.: Static coordination chemistry of metalloporphyrins. In: K. M. Smith: Porphyrins and Metalloporphyrins, p. 179 (Elsevier, Amsterdam, 1975). 2. Cauzzo, G., Gennari, G., Jori, G., and Spikes, J. D.: The effect of the chemical

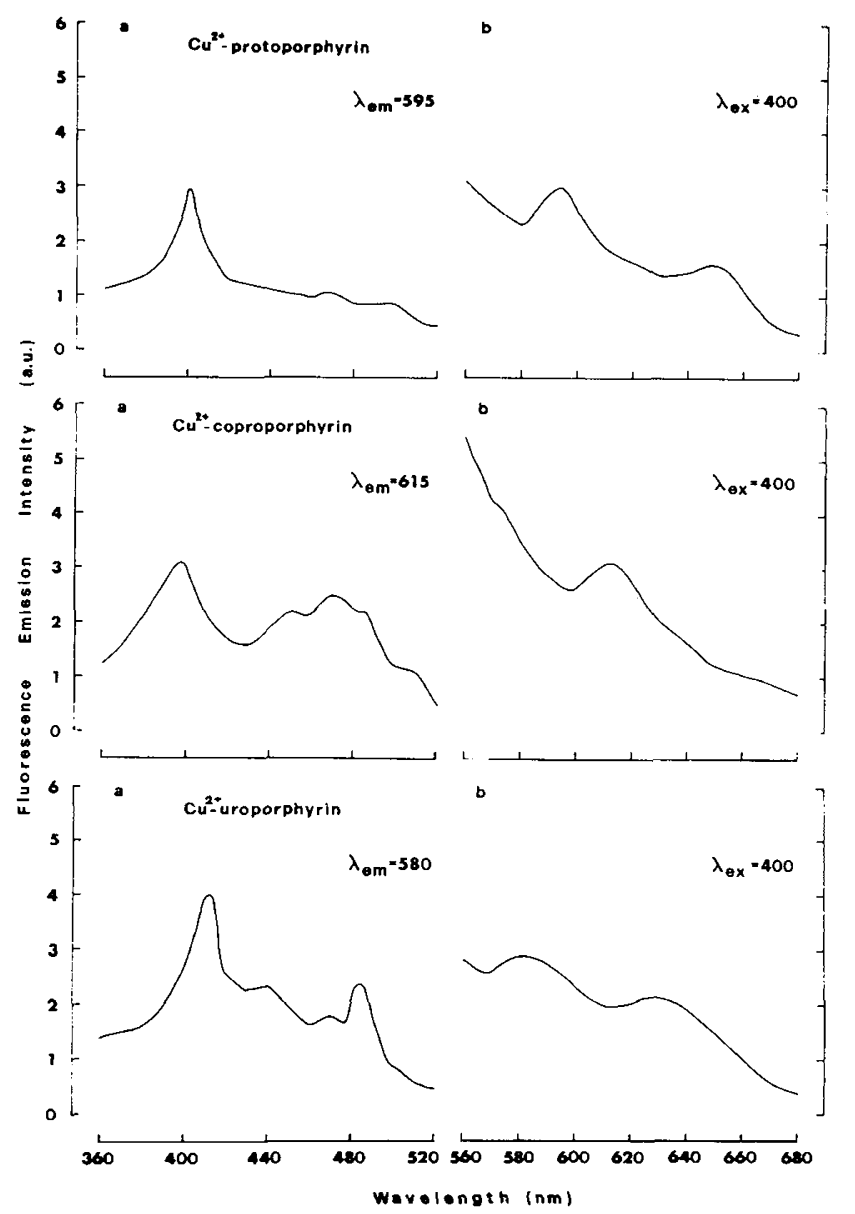

Fig. 4. Fluorescence excitation $(a)$ and emission $(b)$ spectra of the spots, showing a red fluorescence under UV light, in chromatograms obtained by running ether and ethyl acetate extracts from BBS serum on Whatman No. 1 paper (eluent: 2,6-lutidine-water, 40:20, v/v). The spots were eluted from the paper with $3 \mathrm{ml}$ of $0.01 \mathrm{M} \mathrm{NaOH}$ and the solutions were taken to $\mathrm{pH} 7.5$ by addition of $11 \mathrm{M} \mathrm{HCl}$. The identification of the single porphyrins was obtained by comparison of their chromatographic and spectroscopic properties with those of synthetic $\mathrm{Cu}^{2+}$-porphyrins, which were chromatographed in parallel with serum extracts.

structure on the photosensitizing efficiency of porphyrins. Photochem. Photobiol., 25: 389 (1977).

3. Clark, C. F., Torii, S., Hamamoto, Y., and Kaito, H.: The "bronze baby" syndrome: postmortem data. J. Pediatr., 88: 461 (1976).

4. Fuhrtrop, J. H. and Smith, K. M.: Laboratory methods. In: K. M. Smith: Porphyrins and Metalloporphyrins, p. 830 (Elsevier, Amsterdam, 1975).

5. Jackson, A. H.: Modern spectroscopic and chromatographic techniques for the analysis of porphyrins on a microscale. Semin. Hematol., 14: 193 (1977).

6. Jori, G., Rossi, E., and Rubaltelli F. F.: Phototherapy-induced covalent binding of bilirubin to serum albumin. Pediatr. Res., 14: 1363 (1980).

7. Kopelman, A. E., Brown, R. S., and Odell, G. B.: The "bronze" baby syndrome: A complication of phototherapy. J. Pediatr., 81: 466 (1872).

8. Koskelo, P. and Muller-Eberhard, U.: Interaction of porphyrins with proteins. Semin. Hematol., 14: 221 (1977).

9. Rubaltelli, F. F. and Jori, G.: Visible light irradiation of human and bovine serum albumin-bilirubin complex. Photochem. Photobiol., 29: 991 (1979).

10. Rubaltelli, F. F., Jori, G., and Reddi, E.: Bronze baby syndrome. (In preparation).

11. Spikes, J. D.: Porphyrins and related compounds as photodynamic sensitizers. Ann. N. Y. Acad. Sci., 244: 496 (1975).

12. This work was presented in part at the annual meeting of the European Society for Pediatric Research, Berne, September 1981.

13. Requests for reprints should be addressed to: Professor F. F. Rubaltelli, Department of Pediatrics, University of Padova, Via Giustiniani 3, 35100 Padova, Italy.

14. This research was supported in part by CNR grants CT81.00345.04 and CT79.00607.96 under CNR-NSF cooperative research program.

15. Signed informed consent was obtained from parents of patients and controls.

16. Received for publication February 9, 1982.

17. Accepted for publication August 4, 1982. 